\title{
Pengaruh Penggunaan Ampas Kecap Dalam Ransum Terhadap Performa Itik Mojosari
}

\section{The Effect of Soy Sauce Waste in Ration on Performance of Mojosari Duck}

\author{
G. A. A. Larasati*, L. D. Mahfudz dan W. Sarengat \\ Fakultas Peternakan dan Pertanian, Universitas Diponegoro, Semarang, 50275 \\ ${ }^{*}$ E-mail: geaarnanda0212@gmail.com \\ (Diterima: 22 Maret 2017; Disetujui: 24 Mei 2017)
}

\begin{abstract}
ABSTRAK
Penelitian ini bertujuan untuk mengkaji pengaruh dari penggunaan ampas kecap dengan beberapa level pemberian $(0 \% ; 5 \% ; 7,5 \%$ dan $10 \%)$ dalam ransum terhadap performa (konsumsi, produksi telur, konversi ransum) itik Mojosari umur 20 minggu sebanyak 240 ekor dengan bobot badan rata-rata 1.385,0 $\pm 130,85$ gram $(\mathrm{CV}=9,44 \%)$. Bahan pakan yang digunakan yaitu campuran ampas kecap, bekatul, bungkil kedelai, jagung kuning, tepung ikan,pollard dan premix. Perlakuan yang diterapkan yaitu penggunaan ampas kecap 5\%, 7,5\% dan 10\%. Penelitian menggunakan Rancangan Acak Lengkap (RAL) dengan 4 perlakuan dan 6 ulangan. Parameter yang diamati adalah konsumsi ransum, produksi telur, konversi pakan. Data dianalisis dengan analisis ragam atau anova dengan uji F. Hasil penelitian menunjukkan bahwa ampas kecap tidak berpengaruh terhadap performa itik Mojosari (konsumsi ransum, produksi telur, konversi ransum). Kesimpulan dari penelitian ini adalah penggunaan ampas kecap dapat digunakan dalam ransum itik Mojosari sampai level $10 \%$.
\end{abstract}

Kata kunci: itik mojosari, ampas kecap, performa

\section{ABSTRACT}

The purpose of study was to determined the effect of soy sauce waste in ration in the ration on the performance of Mojosari duck. The materials used were 240 of Mojosari which are 20 weeks olds with average body weight 1,385.0 \pm 130.85 grams $(C V=9.44 \%)$. Feed ingredients used were, rice bran, soybean meal, yellow corn, fish meal, pollard and premix. The design that used was Completely Randomized Design (CRD) with 4 treatments and 6 replications.The treatment applied soy sauce waste at level 5, 7.5 and $10 \%$. The parameters observed were consumption, egg production, feed conversion. The data were analyzed by analysis of variance with $F$ test. The results showed that soy sauce waste did not effected on performance (consumption of ration, egg production, ration conversion) of Mojosari duck. The conclusion of this research is soy sauce waste be used as feed stuff of Mojosari duck ration until level 10\%.

Keywords: mojosari duck, ketchup by product, performance

\section{PENDAHULUAN}

Dewasa ini peternakan itik petelur banyak diminati sebagai usaha peternakan unggas penghasil telur yang menguntungkan. Itik Mojosari merupakan salah satu itik lokal yang cukup terkenal di Indonesia, yang berasal dari Desa Modopuro, Kecamatan Mojosari, Kabupaten Mojokerto, Jawa Timur (Suharno dan Amri, 2003).

Faktorkeberhasilandalampemeliharaan itik petelur salah satunya adalah manajemen pakan. Penggunaan pakan yang berkualitas serta sesuai dengan kebutuhan ternak sangat penting dalam menunjang produktivitas. Selain pakan sesuai kebutuhan, diperlukan bahan pakan dengan kandungan nutrient yang mampu mengoptimalkan produktivitas itik petelur. Salah satunya dengan penggunaan ampas kecap di dalam ransum.

Ampas kecap merupakan limbah dari proses pembuatan kecap yang berbahan dasar kedelai dan memiliki kandungan protein tinggi. Ampas kecap dapat digolongkan sebagai 
sumber protein tinggi karena mengandung protein kasar lebih dari 18\% (Mayangsari et al., 2013). Setelah mengalami proses penyaringan, $65 \%$ protein kedelai masih tertinggal pada ampas kecap. Kelebihan lain dari ampas kecap adalah mudah diperoleh dan memiliki harga yang relatif murah. Ampas kecap memiliki kelemahan yaitu kandungan $\mathrm{NaCl}$ yang tinggi di dalamnya yaitu sebesar 20,60\% (Sukarini et al., 2004). Kandungan garam yang tinggi dapat mengganggu konsumsi serta kerja saluran pencernaan sehingga menghambat proses penyerapan nutrient pakan. Tingginya kadar garam pada ampas kecap perlu dilakukan pengolahan diantaranya dengan dilakukan perendaman selama 24 jam dengan larutan asam asetat untuk mengurangi kadar garam (Herdiana et al., 2014).

Ampas kecap memiliki kandungan protein tinggi yang berguna untuk meningkatkan produktivitas itik Mojosari, serta asam amino yang berfungsi untuk membantu proses metabolisme tubuh. Itik petelur dalam masa produksi yaitu umur 20 minggu mempunyai kebutuhan ransum dengan kadar protein $17-19 \%$. Kandungan protein tinggi pada ampas kecap tersebut yang diharapkan mampu menunjang performa itik. Protein dalam ransum berperan untuk menggantikan sel-sel tubuh yang rusak, serta membantu pertumbuhan itik dan juga merupakan unsur pembentukan telur.
Kandungan nitrogen pada protein merupakan salah satu komponen yang tidak dapat digantikan oleh zat hidrat arang maupun lemak. Oleh sebab itu, protein sangat penting dalam ransum baik untuk kelangsungan hidupitik maupun untuk produksinya.

Tujuan dari penelitian yaitu untuk mengkaji pengaruh dari penggunaan ampas kecap dengan beberapa level pemberian $(0 \%$; $5 \% ; 7,5 \%$ dan $10 \%$ ) dalam ransum terhadap performa itik Mojosari.

\section{METODE}

Penelitian ini dilaksanakan pada mulai bulan November 2016 sampai Januari 2017. Materi yang digunakan pada penelitian ini yaitu 240 ekor itik Mojosari umur 20 minggu dengan bobot badan rata-rata 1.385,0 $\pm 130,85$ gram $(\mathrm{CV}=9,44 \%)$. Ampas kecap dan bahan ransum yang terdiri dari bekatul, bungkil kedelai, tepung ikan, pollard, jagung kuning. Kandungan nutrisi bahan pakan dapat dilihat pada Tabel 1. Sedangkan kandungan nutrisi pakan dapat dilihat pada Tabel 2.

Peralatan yang digunakan terdiri dari timbangan kapasitas $50 \mathrm{~kg}$ untuk menimbang bahan pakan, timbangan digital, kandang yang terdiri dari 24 petak dilengkapi dengan tempat pakan, kandang baterai, HCL $10 \%$, tempat minum, thermometer dan hygrometer, egg tray dan sekop.

Tabel 1. Kandungan Nutrisi Bahan Pakan.

\begin{tabular}{clcccccc}
\hline \multirow{2}{*}{ No } & \multirow{2}{*}{ Bahan Pakan } & \multicolumn{7}{c}{ Kandungan Nutrisi } \\
\cline { 2 - 7 } & & $\mathrm{EM}(\mathrm{Kkal} / \mathrm{Kg})^{*}$ & $\mathrm{PK}(\%)^{*}$ & $\mathrm{LK}(\%)^{*}$ & $\mathrm{SK}(\%)^{*}$ & $\mathrm{Ca}(\%)^{* *}$ & $\mathrm{P}(\%)^{* *}$ \\
\hline 1 & Ampas Kecap & 3924,00 & 28,78 & 1,84 & 46,17 & $1,70^{*}$ & $0,70^{*}$ \\
2 & Jagung Kuning & 2785,32 & 9,40 & 4,22 & 2,44 & 0,03 & 0,23 \\
3 & Tepung Ikan & 2091,40 & 37,33 & 5,18 & 2,31 & 12,08 & 3,05 \\
4 & Bekatul & 3395,00 & 12,06 & 13,58 & 8,39 & 0,32 & 1,70 \\
5 & Pollard & 2587,10 & 13,46 & 0,70 & 4,48 & 0,09 & 0,78 \\
6 & Bungkil Kedelei & 2985,05 & 42,84 & 3,00 & 1,90 & 0,24 & 0,57 \\
7 & Premix & 959,43 & 5,26 & 4,23 & 3,35 & $3,30^{*}$ & $3,50 *$ \\
\hline
\end{tabular}

Sumber: * Hasil Analisis Proksimat Laboratorium Ilmu Nutrisi dan Pakan, Fakultas Peternakan dan Pertanian, Universitas Diponegoro.

** Hartadi, 1997 
Tabel 2. Kandungan Nutrisi Bahan Pakan Perlakuan.

\begin{tabular}{lrrrr}
\hline Susunan Ransum & T0 & T1 & T2 & T3 \\
\hline Bahan Pakan: & & & & \\
Ampas Kecap (\%) & 0,00 & 5,00 & 7,50 & 10,00 \\
Bekatul (\%) & 26,20 & 20,00 & 16,50 & 13,70 \\
Bungkil Kedelei (\%) & 17,60 & 14,70 & 13,50 & 12,00 \\
Tepung Ikan (\%) & 7,00 & 7,20 & 7,00 & 7,10 \\
Pollard (\%) & 6,50 & 11,50 & 13,50 & 16,50 \\
Premix (\%) & 1,00 & 1,00 & 1,00 & 1,00 \\
Jagung Kuning (\%) & 41,70 & 40,60 & 41,00 & 39,70 \\
\hline Total & 100,00 & 100,00 & 100,00 & 100,00 \\
\hline Kandungan Nutrisi: & & & & \\
\hline Protein Kasar (\%) & 18,07 & 18,09 & 18,08 & 18,10 \\
Lemak Kasar (\%) & 6,30 & 5,46 & 5,01 & 4,61 \\
Serat Kasar (\%) & 4,04 & 5,97 & 6,91 & 7,90 \\
Kalsium (\%) & 1,02 & 1,11 & 1,12 & 1,16 \\
Posfor (\%) & 0,94 & 0,90 & 0,86 & 0,84 \\
EM (Kcal/kg) & $2.900,00$ & $2.903,00$ & $2.905,00$ & $2.906,00$ \\
\hline Ketergan:
\end{tabular}

Keterangan: * Hasil Analisis Proksimat Laboratorium Ilmu Nutrisi dan Pakan, Fakultas Peternakan dan Pertanian, Universitas Diponegoro, 2016.

Metode pengambilan data yang dilakukan yaitu dengan menghitung konsumsi ransum setiap hari, menimbang bobot badan itik dilakukan setiap minggu untuk mengetahui pertambahan bobot badan harian $(\mathrm{PBBH})$, menghitung produksi telur itik dihitung dari jumlah telur yang diproduksi selama satu minggu dengan jumlah itik yang ada pada minggu tersebut, menghitung konversi ransum dihitung berdasarkan dari jumlah ransum yang dikonsumsi dengan jumlah telur yang diproduksi selama penelitian.

Parameter yang digunakan yaitu konsumsi ransum, dan produksi telur, dan konversi ransum :

1. Konsumsi ransum, diperoleh dari ratarata jumlah pemberian ransum dikurangi jumlah sisa pakan perhari (gram) (Wahju, 2004).

2. Produksi telur, diperoleh dari perbandingan jumlah telur yang dihasilkan perminggu (butir) dengan jumlah itik petelur yang hidup tiap minggu (ekor) dikalikan 100\% (Rasyaf, 1996).

3. Konversi ransum, diperoleh dari perbandingan jumlah konsumsi ransum perminggu (kilogram) dengan bobot telur yang dihasilkan perminggu atau dalam kurun waktu yang sama. (Septyana, 2008).

\section{HASIL DAN PEMBAHASAN}

\section{Pengaruh Perlakuan terhadap Konsumsi Ransum}

Hasil analisis ragam menunjukkan bahwa perlakuan tanpa ampas kecap dan penggunaan ampas kecap taraf 5\%, 7,5\%, $10 \%$ dalam ransum tidak berpengaruh nyata $(\mathrm{P}>0,05)$ terhadap konsumsi ransum itik Mojosari (Tabel 3). Tidak adanya perbedaan nyata pada konsumsi ransum itik dapat dipengaruhi oleh tingkat kecernaan protein kasar. Konsumsi ransum menentukan kandungan protein yang dikonsumsi itik, dimana kandungan protein yang terdapat dalam ransum menentukan sedikit banyaknya protein yang tercerna oleh itik. Ampas kecap mengandung senyawa Isoflavon, senyawa isoflavon adalah senyawa aktif yang berasal dari biji kedelai dan ditemui dalam bentuk 
Tabel 3. Pengaruh Penggunaan Ampas Kecap Dalam Ransum Terhadap Performa Itik Mojosari.

\begin{tabular}{lcccc}
\hline Parameter & T0 & T1 & T2 & T3 \\
\hline Konsumsi ransum (g/ekor/minggu) & 819,19 & 816,31 & 817,27 & 818,27 \\
Produksi telur (\%) & 18,69 & 19,26 & 19,70 & 16,64 \\
Konversi ransum & 13,64 & 14,42 & 13,74 & 15,68 \\
\hline
\end{tabular}

Keterangan : Hasil menunjukkan tidak berbeda nyata $(\mathrm{P}>0,05)$.

glikosida. Glikosida mengalami degradasi dan akan mudah diserap oleh usus halus dalam bentuk yang lebih sederhana yaitu aglikon. Adanya senyawa isoflavon pada ampas kecap menyebabkan metabolisme bakteri yang mempengaruhi penyerapan nutrient dalam saluran pencernaan khususnya protein menjadi optimal dan berakibat pada tingginya protein yang tercerna. Hal ini sesuai dengan pendapat Winedar et al., (2006) bahwa tinggi rendahnya nilai kecernan protein pakan ditentukan oleh jumlah protein yang dikonsumsi, semakin sedikit jumlah protein yang dibuang bersama eksreta maka akan meningkatkan kecernaannya. Kualitas ransum juga dapat mempengaruhi kecernaan protein pada itik, bila ransum yang diberikan memiliki kandungan energi yang tinggi maka itik akan mengkonsumsi pakan lebih sedikit, karena itik akan berhenti makan ketika kebutuhan energinya terpenuhi.

Tingkat konsumsi juga dapat dipengaruhi oleh umur itik, keadaan lingkungan, serta temperatur lingkungan. Tidak adanya perbedaan nyata pada konsumsi ransum itik dapat dipengaruhi oleh umur itik, keadaan lingkungan, serta temperatur lingkungan. Hal ini sesuai dengan pendapat Williamson dan Payne (1993) faktor utama yang mempengaruhi konsumsi harian ransum itik yaitu suhu lingkungan dan kandungan kalori dalam ransum. Selain itu konsumsi ransum itik yang tidak berpengaruh nyata dapat dipengaruhi oleh tingkat penggunaan kandungan protein kasar (iso protein) yang sama, kandungan energi metabolisme (iso energi) yang tidak berbeda di dalam ransum (Tabel 2) sehingga konsumsi ransum tidak berbeda nyata. Hal ini sesuai dengan pendapat Yuwanta (1988) yang menyatakan bahwa peningkatan tingkat protein secara konsisten tidak diikuti dengan peningkatan jumlah konsumsi pakan. Tidak adanya perbedaan konsumsi pakan antar tingkat protein disebabkan besarnya energi metabolis dan rata-rata temperatur ruangan penelitian relatif sama. Dewanti (2010) menyatakan bahwa perbedaan iso protein dan isoenergi pada imbangan yang sama tidak mempengaruhi kecepatan pertumbuhan, melainkan berpengaruh terhadap konsumsi dan konversi ransum.

Kandungan energi metabolism yang juga sama di dalam ransum mempengaruhi konsumsi ransum ternak. Konsumsi ransum pada ternak sangat dipengaruhi kandungan energinya. Konsumsi ransum akanmeningkat apabila diberi ransum dengan kandungan energi yang rendah dan sebaliknya akan menurun apabila diberi ransum dengan kandungan energi yang tinggi. Hal ini disebabkan karena unggas mengkonsumsi ransum terutama untuk memenuhi kebutuhan energinya (Anggorodi, 1995). Sudaryani dan Santoso (1994) menyatakan ransum pada unggas petelur dibutuhkan untuk berbagai kegunaan antara lain untuk memenuhi kebutuhan hidup pokok, perbaikan jaringan atau sel yang rusak, pertumbuhan tubuh, pertumbuhan bulu dan produksi telur. Menurut Agustina et al., (2013) nutrien yang terserap sempurna dalam tubuh akan meningkatkan konsumsi pakan ternak sehingga pertumbuhan dan produksi akan semakin baik.

\section{Pengaruh Perlakuan terhadap Produksi Telur}

Berdasarkan hasil analisis ragam menunjukkan bahwa penggunaan ampas kecap dalam ransum tidak berpengaruh secara nyata $(\mathrm{P}>0,05)$ terhadap produksi telur 
(Tabel 3). Penggunaan ampas kecap (T1, $\mathrm{T} 2$, dan T3) dalam ransum dengan ransum yang tidak menggunakan ampas kecap (T0) tidak menunjukkan perbedaan yang nyata terhadap produksi telur. Hal ini dikarenakan itik yang digunakan merupakan itik periode awal bertelur, umur itik yaitu 22-28 minggu sehingga produksi telur yang dihasilkan itik masih rendah. Produksi telur itik juga dapat dipengaruhi oleh kondisi lingkungan, pakan, faktor genetik. Hal ini sesuai dengan pendapat Rasyaf (1991) yang menyatakan faktor-faktor yang mempengaruhi tinggi atau rendahnya kemampuan produksi telur yaitu keinginan unggas untuk menyesuaikan diri dengan alam lingkungannya dan kemampuan bertelur unggas ditentukan oleh kemampuan genetisnya.

Produksi telur yang dihasilkan selama penelitian menunjukkan hasil yang cukup rendah. Hal ini dapat disebabkan pengaruh umur itik, serta kondisi lingkungan. Hal ini sesuai dengan pendapat Muslim (1992) produksi telur dipengaruhi oleh dua faktor penting yaitu faktor lingkungan dan genetik. Faktor genetik yang mempengaruhi produksi telur adalah umur masak kelamin, sedangkan faktor lingkungan adalah pakan, pemeliharaan, suhu lingkungan dan kesehatan. Menurut Ketaren et al., (2002) menyatakan bahwa itik petelur umur 22-42 minggu sebaiknya diberi pakan secara ad libitum atau dalam jumlah yang tidak terbatas. Kualitas ransum juga sangat penting dalam peningkatankemampuan produksi telur itik. Menurut Prasetyo dan Ketaren (2005) menyatakan pemberian ransum dengan kandungan protein pakan yang rendah (14\%) akan menghasilkan puncak produksi yang lebih rendah dibandingkan dengan pemberian pakan dengan kandungan protein pakan yang lebih tinggi (20\%), dan juga perlu diperhatikan imbangan energi:protein dalam pakan tersebut.

\section{Pengaruh Perlakuan terhadap Konversi Ransum}

Berdasarkan hasil analisis ragam menunjukkan bahwa penggunaan ampas kecap dalam ransum tidak berpengaruh secara nyata $(\mathrm{P}>0,05)$ terhadap konversi pakan (Tabel 3). Penggunaan ampas kecap dalam ransum maupun tanpa ampas kecap dalam ransum menghasilkan konversi yang sama. Diperoleh hasil nilai rata-rata konversi pakan yaitu 14,37 . Nilai konversi pakan yang tinggi tersebut disebabkan oleh produksi telur yang rendah, produksi telur yang rendah disebabkan karena itik periode awal bertelur. Hal ini sesuai dengan pendapat Zubaidah (1991) yang menyatakan konversi ransum tergantung pada jumlah pakan yang dikonsumsi, jumlah dan bobot telur yang dihasilkan.

Bila jumlah telur yang dihasilkan banyak akan menyebabkan konversi pakan yang kecil bila dibandingkan dengan itik yang berproduksi sedikit walaupun konsumsi dan bobot telur sama. Nilai konversi ransum berkaitan dengan efisiensi penggunaan pakan. Hal ini sesuai dengan pendapat Septyana (2008) konversi ransum merupakan cara untuk mengukur efisiensi penggunaan ransum yaitu perbandingan antara jumlah ransum yang dikonsumsi pada waktu tertentu dengan produksi yang dihasilkan (pertambahan bobot badan atau jumlah bobot telur) dalam kurun waktu yang sama. Menurut Hy-Line International (1986), nilai konversi itik petelur masih sangat buruk yaitu berkisar antara 3,25,0 dibandingkan dengan ayam ras petelur yang dalam setahun produksi hanya berkisar $2,4-2,6$.

\section{KESIMPULAN}

Berdasarkan hasil penelitian, dapat diperoleh kesimpulan bahwa ransum dengan penggunaan ampas kecap belum mampu mempengaruhi konsumsi ransum, produksi telur dan konversi ransum itik Mojosari. Saran yang dapat disampaikan yaitu perlu dilakukan penelitian lebih lanjut mengenai penggunaan ampas kecap dalam ransum itik petelur, selain itu sebaiknya itik yang digunakan bukan itik periode awal produksi. 


\section{DAFTAR PUSTAKA}

Anggorodi, R. 1995. Nutrisi Aneka Ternak Unggas. PT. Gramedia Pustaka. Jakarta.

Agustina, D., N. Iriyanti dan S. Mugiyono. 2013. Pertumbuhan dan konsumsi pakan pada berbagai jenis itik lokal betina yang pakannya di suplementasi probiotik. J. Ilmiah Peternakan. 1 (2) : 691-698.

Andayani, D., M. Yanis dan B. Bakrie. 2001. Perbandingan produktivitas itik Mojosari dan itik lokal pada pemeliharaan secara intensif di DKI Jakarta. Pros. Seminar Nasional Teknologi Peternakan dan Veteriner. Bogor, 17 - 18 September 2001. Puslitbang Peternakan, Bogor. hlm.: $533-541$.

Bidura, I. G. N. G. 2007. Aplikasi Produk Bioteknologi Pakan ternak. Penerbit Udayana University Press, Denpasar.

Dewanti, R. 2010. Pengaruh Pejantan dan Pakan Terhadap Fenotip Pertumbuhan Itik Turi Sampai Umur Delapan Minggu. Seminar Nasional Unggas Lokal ke IV. Fakultas Peternakan Universitas Diponegoro. Hal 153-159.

Ensminger M. E. 1992. Poultry Science. Ed ke-3. USA: Interstate.

Hardjosworo, P. dan Rukmiasih. 1999. Itik Permasalahan dan Pemecahan. Penebar Swadaya, Jakarta.

Herdiana R. M., Y. Marshal, R. Dewanti dan Sudiyon. 2014. Pengaruh penggunaan ampas kecap dalam pakan terhadap pertambahan bobot badan harian, konversi pakan, rasio efisiensi protein, dan produksi karkas itik lokal jantan umur delapan minggu. Universitas Sebelas Maret. Surakarta. Buletin peternakan. 38 (3) : 157-162.

Hy-Line International. 1986. Hy-Line Variety Brown, Comemercial Management Guide.A. publication of Hy-line international, West Des Moines, lowa.
Ketaren, P. P. dan L. H. Prasetyo. 2002. Pengaruh pemberian pakan terbatas terhadap produktivitas itik silang Mojosari X Alabio (MA) selama 12 bulan produksi, Balai Penelitian Ternak. Bogor.

Ketaren, P. P. 2006. Optimalisasi pemanfaatan wheat bran untuk produksi daging unggas melalui imbuhan enzim xilanase dan - glukanase: Itik pedaging. Pros. Seminar Nasional Bioteknologi. Cibinong, 15-16 Nopember 2006. Puslit Bioteknologi, LIPI, Cibinong, Bogor. hlm. 325-331.

Ketaren, P. P. 2007. Peran itik sebagai penghasil telur dandaging nasional. Wartazoa 17: 117-127.

Mayangsari N. S., A. Subrata dan M. Christiyanto. 2013. Pengaruh proteksi protein ampas kecap dengan tanin terhadap konsentrasi amonia, produksi protein total dan persentase rumen undegraded dietary protein secara in vitro. Fakultas Peternakan dan Pertanian, Universitas Diponegoro, Semarang. J. 2 (1) : $261-268$.

Mulyokusumo, S. E. 1974. Kecap. Terate. Bandung.

Mirnawati. W. I. 2001. Pengaruh Penggunaan Ampas Kecap yang Direndam dengan Asam Asetat dalam Ransum terhadap Kondisi Awal Peneluran Burung Puyuh. Skripsi S1. Fakultas Peternakan Universitas Diponegoro, Semarang.

Murtidjo, B. 1988. Mengelola ltik. Yogyakarta: Penerbit Kanisius.

Muslim, D. A. 1992. Budidaya Mina Itik. Cetakan Pertama. Penerbit Kanisius, Yogyakarta.

NRC., 1994. Nutrien Requirement of Poultry. National Academy Science. Washington.

Nugraha, D., U. Atmomarsono dan L. D. Mahfudz. 2012. Pengaruh penambahan eceng gondok (Eichornia crassipes) fermentasi dalam ransum terhadap 
produksi telur itik Tegal. Fakultas Peternakan Universitas Diponegoro Animal Agricultural Journal, Vol. 1. No. 1, 2012, p $75-85$.

Parakkasi, A. 1983. Ilmu Gizi dan Makanan Ternak Monogastrik. Angkasa. Bandung.

Prasetyo, L. H., dan P. P. Ketaren. 2005. Interaksi antar bangsa itik dan kualitas ransum pada produksi dan kualitas itik lokal. Proseding. Seminar. Nasional Teknologi Peternakan dan Veteriner. Pusat Penelitian dan Pengembangan Peternakan. Bogor 12-13 September. P: 811-816.

Ranto dan M. Sitanggang. 2005. Panduan lengkap beternak Itik. Cetakan Pertama. Agro Media. Jakarta.

Rasyaf, M. 1991. Pengelolaan produksi telur. Edisi Kedua. Penerbit Kanisius. Yogyakarta.

Rasyaf, M. 1993. Beternak Itik Komersial. Edisi kedua. Penerbit Kanisius, Yogyakarta.

Rasyaf, M. 1996. Beternak Ayam Petelur. Penebar Swadaya. Anggota IKAPI. Jakarta.

Rizal, Y. 2006. Ilmu Nutrisi Unggas. Yogyakarta: Andalas University Press.

Sastrosupadi, A. 2000. Rancangan Percobaan Praktis Bidang Pertanian. Penerbit Kanisus. Yogyakarta.

Scott, M. L., M. C. Nesheim and R. J. Young. 1982. Nutrition of The Chicken. 3rd Edition. M. L. Scott dan Associates Ithaca. New York.

Septyana M. 2008. Performa Itik Petelur Lokal Dengan Pemberian Tepung Daun Katuk (Sauropus Androgynus (L.) Merr.) Dalam Ransumnya. Program Studi Ilmu Nutrisi Dan Makanan Ternak Fakultas Peternakan Institut Pertanian Bogor. Bogor. (Skripsi).

Shen, T. F . 1985 . Nutrient requirement of egg-laying ducks. In : Duck Production Science and World Practice . (D.J.
Farrel and P. Stapleton, Eds.). The University of New England, Armidale. Australia

Simanjuntak, L. 2004. Tik Tok Unggas Pedaging Hasil Persilangan Itik \& Entok. Agromedia Pustaka. Jakarta.

Sinurat, A. P., P. Ketaren, P. Setiadi, A. Lasmini dan A. R. Setioko. 1995 . Kebutuhan fosfor (P) untuk itik petelur. Prosidings Seminar Sains dan Teknologi Petemakan. Balai Penelitian Temak, Bogor. Hal. 202-206.

Sinurat, A. P. 2000. Penyusunan ransum ayam buras dan itik. Pelatihan proyek pengembangan agribisnis peternakan, Dinas Peternakan DKI Jakarta, 20 Juni 2000.

Srigandono, B. 1997. Ilmu Unggas Air. Gadjah Mada Press. Yogyakarta.

Sudaryani, T. dan H. Santoso. 1994. Pembibitan Ayam Ras, Penebar Swadaya Jakarta.

Suharno, B. 2010. Beternak itik secara intensif. Penebar Swadaya. Jakarta.

Suharno, B. dan K. Amri. 2003. Beternak Itik Secara Intensif. Cetakan kedelapan. Penebar Swadaya. Jakarta.

Sukarini, N. E., L. D. Mahfudz dan A. M. Legowo. 2004. Pengaruh penggunaan ampas kecap yang diproses dengan larutan asam asetat untuk pakan terhadap komposisi kimia daging dada ayam broiler. Jurnal Pengembangan Peternakan Tropis, 29 (3): 129-135.

Supriyadi. 2002. Itik Petelur Unggul. Penebar swadaya, Jakarta.

Wahju, J. 2004. Ilmu Nutrisi Unggas. Gadjah Mada University Press, Yogyakarta.

Widayati, E. dan Y. Widalestari. 1996. Limbah untuk Pakan Ternak. Trubus Agrisarana. Surabaya.

Williamson, G. and W. J. A. Payne, 1993. Pengantar Peternakan di Daerah Tropis, Universitas Gajah Mada, Yogyakarta.

Winedar, H., S. Listyawati dan Sutarno. 2006. 
Daya Cerna Protein Pakan, Kandungan Protein Daging, dan Pertambahan Berat Badan Ayam broiler setelah Pemberian Pakan yang Difermentasi dengan Effective Microorganisms-4 (EM-4). Jurnal Bioteknologi. 3 (1) Hal : 14-19.

Yuwanta, T. 1998. Performance of Asia Native Ducks Raised Under Extensive Rural
Condition. Proc. 6th. APPC. Nagoya, Japan.

Zubaidah. 1991. Performans produksi telur hasil persilangan itik Alabio dengan itik bibit induk CV 2000 pada generasi pertama. Tesis. Fakultas Pascasarjana. Institut Pertanian Bogor, Bogor. 